\title{
Effects of Peer Support Program on Self-Management in Patients with End-Stage Renal Disease Undergoing Hemodialysis
}

\author{
Fida' Husain ${ }^{1}$, Henni Kusuma ${ }^{2}$, Andrew Johan ${ }^{3}$ \\ ${ }^{I}$ Faculty of Health Sciences, 'Aisyiyah University of Surakarta, Surakarta, Indonesia \\ ${ }^{2}$ Department of Nursing, Faculty of Medicine, Universitas Diponegoro, Semarang, Indonesia \\ ${ }^{3}$ Department of Biochemistry, Faculty of Medicine, Universitas Diponegoro, Semarang, Indonesia \\ Corresponding Author: Fida' Husain (fida.husain93@gmail.com)
}

\begin{abstract}
Background: Patients with End-Stage Renal Disease (ESRD) undergoing hemodialysis require proper self-management of lifestyle changes to minimize risks of complications, morbidity, and mortality. Efforts made to improve self-management in hemodialysis patients in previous studies were mostly carried out by health workers that may not provide 'real' knowledge, while peer support programs carried out by patients as peers to share their experiences may provide more benefits.

Purpose: The purpose of this study was to determine the effects of peer support programs on improving self-management in patients with ESRD undergoing hemodialysis.

Methods: This study employed a quasi-experimental design and involved a total of 33 patients in the control group and 32 patients in the intervention group, who met the inclusion and exclusion criteria. The samples were recruited consecutively. The intervention of peer support programs was implemented through information support, emotional support, and mutual reciprocity in groups of 10-12 people to share experiences related to their self-management. The intervention was given for six sessions; each lasted for 30-45 minutes. The data were collected using the Indonesian version of the hemodialysis self-management instrument (HDSMI) and analyzed using the pairedsample t-test and independent-sample t-test.

Results: The results showed that after the intervention, the mean score of selfmanagement in the intervention group increased from $79.47 \pm 7.919$ to $90.75 \pm 7.089$, and in the control group, the mean increased from $81.88 \pm 8.291$ to $82.12 \pm 7.692$. After the implementation of peer support programs, there was a significant difference in the score of self-management between the intervention group and the control group $(\mathrm{p}<0.001)$.

Conclusion: Peer support programs gave an effect on increasing self-management in patients with ESRD undergoing hemodialysis. Peer support programs should be introduced early to ESRD patients undergoing hemodialysis so that they can learn about self-management from other patients.
\end{abstract}

Keywords: End-stage renal disease; hemodialysis; peer support; self-management 
How to Cite: Husain, F., Kusuma, H., \& Johan, A. (2020). Effects of peer support program on self-management in patients with end-stage renal disease undergoing hemodialysis. Nurse Media Journal of Nursing, 10(2), 172-182. doi:10.14710/nmjn.v10i2.26502

Permalink/DOI: https://doi.org/10.14710/nmjn.v10i2.26502

\section{BACKGROUND}

Kidney failure is recognized as a major health problem that contributes to an increased rate of morbidity and mortality. Global Burden of Disease (GBD) shows that there are 1.2 million people died from kidney failure in 2015, with an increase of $32 \%$ since 2005 (Wang et al., 2016). In Indonesia, the data from the basic health research showed that there is an increased prevalence of End-Stage Renal Disease (ESRD) from 0.2\% in 2013 to $0.38 \%$ in 2018 (Ministry of Health Republic of Indonesia [MoHRI], 2019). Patients with ESRD require therapies to replace decreased kidney function, including hemodialysis (HD), peritoneal dialysis (PD), and kidney transplant (Smeltzer, Bare, Hinkle, \& Cheever, 2010).

Hemodialysis is the most widely used kidney replacement therapy for ESRD patients. A majority of patients chose HD (86.9\%) over PD (10.1\%), and kidney transplant $(2.9 \%)$ as the modality in the USA (Saran et al., 2019). The number of patients undergoing HD in Indonesia increased dramatically in the last 3 years, recorded as many as 52,835 patients in 2016, 77,892 patients in 2017, and 132,142 patients in 2018 (Indonesian Renal Registry, 2018).

The global mortality rate of hemodialysis patients is 16.9-26.7 (death/100 patients per year) in the first year (Robinson et al., 2014). Cardiovascular disease (CVD) is a highly common complication and becomes the first cause of death in ESRD patients (Cozzolino et al., 2018; Magalhaes et al., 2017). Hemodialysis requires essential lifestyle changes such as consistent attendance at a dialysis unit for treatment, restriction of fluid intake, diet, and taking medications (Li, Jiang, \& Lin, 2014). Such lifestyle changes are strongly influenced by increasing self-management.

Self-management is a collaborative activity between patients and health workers that aims to minimize the impact of chronic diseases on health status and function, through managing diseases, making decisions about needed self-care, identifying problems, setting goals, and monitoring and managing symptoms that arise (Rijken, Jones, Dixon, \& Anna, 2008; Ryan, 2009). Most of the patients with ESRD undergoing HD (57.4\%) in a previous study reported lower self-management levels (Gela \& Mengistu, 2018). Efforts to improve self-management in HD patients and maintain the patients' condition to remain optimal are ways to reduce mortality, morbidity and improve the quality of life of patients (Guney et al., 2012; Lin, Liu, Hsu, \& Tsai, 2017). Interventions to improve selfmanagement may include education and counseling, self-management programs, selfefficacy training, self-monitoring programs, and social support (Husain, Johan, \& Kusuma, 2019). 
The self-management of HD patients is influenced by knowledge, self-efficacy, and social support (Li et al., 2014). Research showed that positive social facilitation enhances self-regulation and engagement in self-management behaviors (Ryan, 2009). Health literacy and social support play independent positive roles in the self-management behavior of patients with kidney disease, with social support having a particularly dominant role (Chen et al., 2018). Social support through peer support programs in previous studies was evident to improve adherence to treatment management in chronic conditions (Haidari, Moeini, \& Khosravi, 2017; Yin et al., 2015).

In previous studies, peer support programs in HD patients had focused on psychological outcomes (Irajpour, Hashemi, Abazari, Shahidi, \& Fayazi, 2018; Malek-Khahi, Milani, \& Amiri, 2015), and carried out by health workers (Mahjubian, Bahraminejad, \& Kamali, 2018). While health workers may not be able to provide 'real' knowledge that is derived from the real-life experience of HD patients, how it feels, and how self-management is implemented (Taylor, Gutteridge, \& Willis, 2016), it is, therefore, important to investigate how peer support affects self-management in HD patients.

\section{PURPOSE}

This study aimed to determine the effects of peer support programs on improving selfmanagement in patients with end-stage renal disease (ESRD) undergoing hemodialysis.

\section{METHODS}

\section{Research design and samples}

This study used a pre-test and post-test quasi-experimental design with a control group. The samples were HD patients in a public hospital in Semarang, Indonesia, recruited by consecutive sampling with a total of 33 patients in the control group and 32 patients in the intervention group. The inclusion criteria were ESRD patients undergoing routine HD twice a week for $\geq 3$ months, aged $\geq 18$ and $\leq 65$ years old, compos mentis, willing to complete a series of peer support programs, not having hearing loss and verbal disorders, graduating from elementary to high school, and being able to read and communicate in the Indonesian language. The exclusion criteria were patients with hospitalization and experienced major depression and dementia. The participants' flowchart in this study is presented in Figure 1.

\section{Measurements}

The self-management measurement tool in HD patients was stated in Li et al. (2014), i.e., the HD Self-Management Instrument (HDSMI), consisting of four components, namely partnership, problem-solving, self-care, and emotional management. The researchers used the Indonesian version of the questionnaire as used in a previous study by Astuti (2016). The questionnaire consisted of 32 items and was declared valid and reliable with a validity value of 0.331-0.799 and an alpha Cronbach value of 0.898 (Astuti, 2016). This instrument was used to measure patients' self-management before (pre-test) and after (post-test) the intervention of peer support programs.

\section{Data collection procedure}

One week before the intervention, the patients filled out the self-management questionnaire that had been prepared (pre-test). Peer support programs through 
informational support, emotional support, and mutual reciprocity were carried out in groups of 10-12 people to share the experiences of self-management for 6 times, 2 times/week, and 30-45 minutes per meeting.

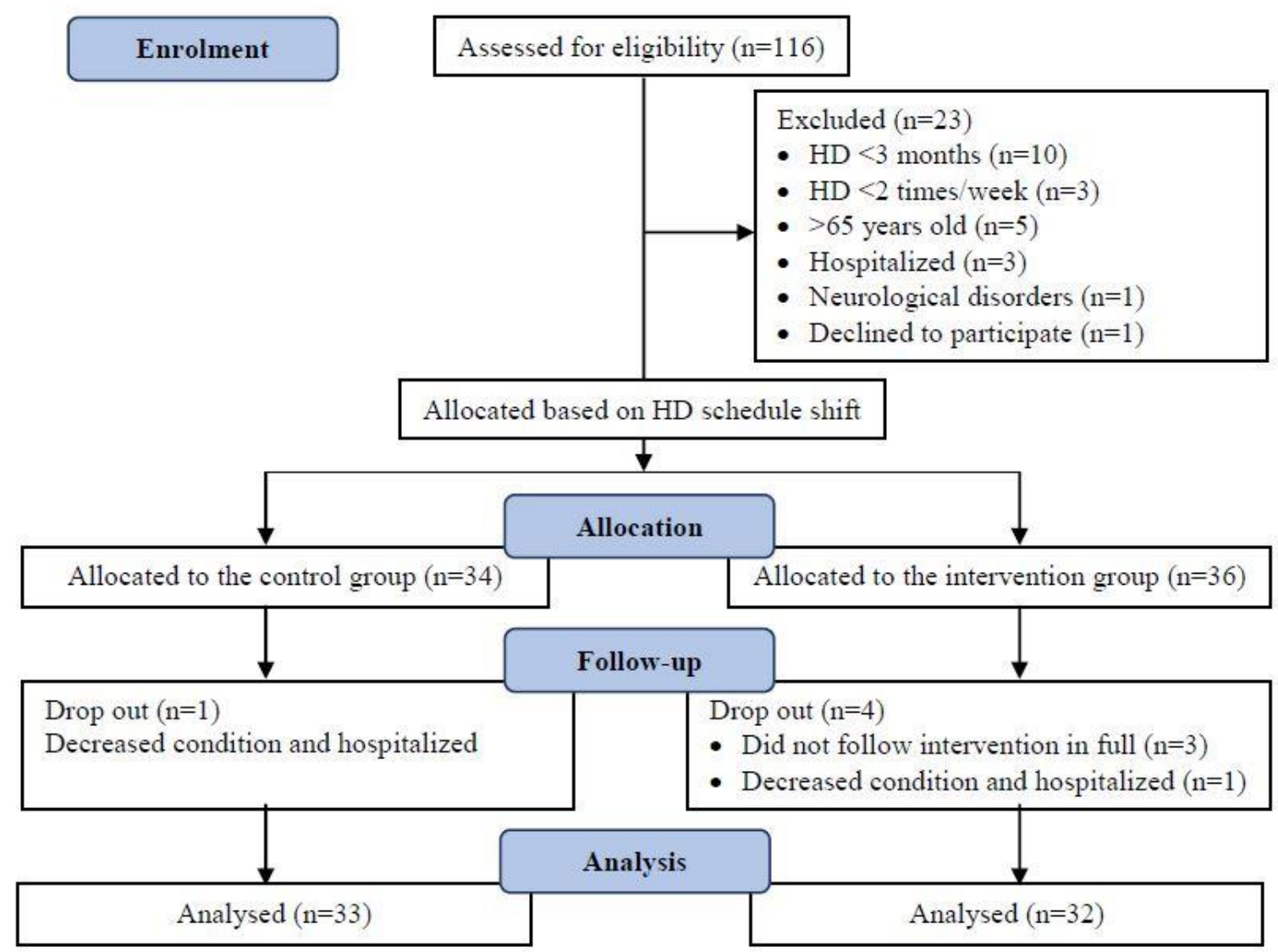

Figure 1. Participants flowchart in the study

The intervention activities are presented in Table 1 . One week after the intervention, the patients were measured for self-management using the same questionnaire (post-test). In this study, the patients in the control group were given peer support program manuals books and education about HD self-management after the post-test.

Table 1. Schedule of peer support programs

\begin{tabular}{cll}
\hline Session & \multicolumn{1}{c}{ Activities } & \multicolumn{1}{c}{ Description } \\
\hline Session 1 & $\begin{array}{l}\text { Formation of } \\
\text { group and } \\
\text { selection of } \\
\text { peer leaders }\end{array}$ & $\begin{array}{l}\text { Patients were grouped based on the same shift schedule. } \\
\text { Researchers distributed peer support program manual books and } \\
\text { led discussions to explore difficulties regarding self-management } \\
\text { in patients. Each group determined the peer leader and planned } \\
\text { further discussions. Peer leaders were selected based on group } \\
\text { agreement and those who were willing to lead the discussion in } \\
\text { the group. Researchers explained the role of the peer leaders. }\end{array}$ \\
\hline
\end{tabular}




\begin{tabular}{|c|c|c|}
\hline Session & Activities & Description \\
\hline Session 2 & $\begin{array}{l}\text { Fluid } \\
\text { restriction } \\
\text { management }\end{array}$ & $\begin{array}{l}\text { Peer leaders led the groups to share experiences on non- } \\
\text { compliance with fluid restrictions (e.g., swelling, shortness of } \\
\text { breath), and on strategies for limiting fluid, how to calculate the } \\
\text { maximum fluid consumption, how to manage thirst, and how to } \\
\text { monitor interdialytic weight gain (IDWG). }\end{array}$ \\
\hline Session 3 & $\begin{array}{l}\text { Nutrition } \\
\text { management }\end{array}$ & $\begin{array}{l}\text { Peer leaders led members to share their experiences of foods that } \\
\text { might cause health problems, difficulties in choosing food, and } \\
\text { the solutions. Group members also shared experiences of the } \\
\text { amount and how to consume fruits and vegetables for HD } \\
\text { patients, as well as strategies for choosing foods to be consumed. }\end{array}$ \\
\hline Session 4 & $\begin{array}{l}\text { Treatment } \\
\text { management } \\
\text { and } \\
\text { hemodialysis } \\
\text { adequation }\end{array}$ & $\begin{array}{l}\text { Peer leaders asked members whether they had missed any HD } \\
\text { schedules (skipping HD), and complaints that they experienced } \\
\text { due to such absence. Group members also shared their past } \\
\text { experiences of average time needed for completing an HD } \\
\text { schedule, reasons for uncompleted HD (accelerated due to } \\
\text { complications, e.g., cramps, hypotension). They also advised } \\
\text { each other related to the drugs consumed, such as name, use, side } \\
\text { effects, and how to meet the adequacy of hemodialysis (arriving } \\
\text { on time, on time HD, and limiting weight gain). }\end{array}$ \\
\hline Session 5 & $\begin{array}{l}\text { Emotional } \\
\text { management }\end{array}$ & $\begin{array}{l}\text { Peer leaders asked group members whether they often felt angry } \\
\text { easily, and things they usually did to express the emotion. } \\
\text { Exploration of solutions and tips for managing stress and anger, } \\
\text { as well as practicing deep breathing relaxation with group } \\
\text { members were also conducted. }\end{array}$ \\
\hline Session 6 & $\begin{array}{l}\text { Evaluation } \\
\text { and follow-up } \\
\text { plan }\end{array}$ & $\begin{array}{l}\text { Peer leaders and members explored feelings during the activity, } \\
\text { advised each other, and determined the sustainability plan of the } \\
\text { groups that had been established. }\end{array}$ \\
\hline
\end{tabular}

\section{Data analyses}

Data on the characteristics of participants such as gender, age, education, occupation, family income, the period of dialysis, and co-morbidities were analyzed using descriptive statistics. The homogeneity of the two groups was tested using the Chi-square test. The data normality on self-management was examined using the Shapiro Wilk test, and the result showed that the data were normally distributed. The paired t-test was used to analyze the mean difference before and after the intervention, while the independent $\mathrm{t}$ test was used to compare the mean differences between the intervention and the control groups in this study.

\section{Ethical considerations}

This study was approved by the Health Research Ethics Committee of Tugurejo Hospital Semarang with number 57/KEPK.EC/IV/2019. Informed consent was obtained from all patients. Important information related to the purpose of the study, procedures, risk, and benefits of the study were explained to the patients. The confidentiality of the patients was also maintained throughout the study. 


\section{RESULTS}

\section{Characteristics of participants}

The characteristics of participants in the intervention group and the control groups in this study showed a $p$-value of $>0.05$, indicating no statistically significant difference between the two groups. Table 2 shows that the majority of the participants in both groups were males $(66.2 \%)$, late adults (41-65 years old) (78.5\%), graduated from high school (50.8\%), unemployed (60\%), family income/month <IDR 2,500,000 (58.5\%), period of dialysis $<1$ year (40\%), and had 1 co-morbid disease $(53.8 \%)$.

Table 2. Characteristics of participants in the control and the intervention groups $(n=65)$

\begin{tabular}{|c|c|c|c|c|c|}
\hline \multirow[t]{3}{*}{ Variable } & \multicolumn{4}{|c|}{ Groups } & \multirow{3}{*}{$p$} \\
\hline & \multicolumn{2}{|c|}{$\begin{array}{l}\text { Control Group } \\
(n=33)\end{array}$} & \multicolumn{2}{|c|}{$\begin{array}{c}\text { Intervention Group } \\
(n=32)\end{array}$} & \\
\hline & $f$ & $\%$ & $f$ & $\%$ & \\
\hline \multicolumn{6}{|l|}{ Gender } \\
\hline Male & 21 & 63.6 & 22 & 68.8 & \multirow{2}{*}{$0.862 *$} \\
\hline Female & 12 & 36.4 & 10 & 31.3 & \\
\hline \multicolumn{6}{|l|}{ Age } \\
\hline Early Adult (18-40 years old) & 8 & 24.2 & 6 & 18.8 & \multirow{2}{*}{$0.813 *$} \\
\hline Late Adult (41-65 years old) & 25 & 75.8 & 26 & 81.3 & \\
\hline \multicolumn{6}{|l|}{ Education } \\
\hline Elementary School & 10 & 30.3 & 9 & 28.1 & \multirow{3}{*}{$0.930 *$} \\
\hline Junior High School & 7 & 21.2 & 6 & 18.8 & \\
\hline High School & 16 & 48.5 & 17 & 53.1 & \\
\hline \multicolumn{6}{|l|}{ Occupation } \\
\hline Employed & 14 & 42.4 & 12 & 37.5 & \multirow{2}{*}{$0.879 *$} \\
\hline Unemployed & 19 & 57.6 & 20 & 62.5 & \\
\hline \multicolumn{6}{|l|}{ Family Income/Month } \\
\hline$<$ IDR 2,500,000 & 18 & 54.5 & 20 & 62.5 & \multirow{2}{*}{$0.690 *$} \\
\hline$\geq$ IDR 2,500,000 & 15 & 45.5 & 12 & 37.5 & \\
\hline \multicolumn{6}{|l|}{ Period of Dialysis } \\
\hline$<1$ year & 12 & 36.4 & 14 & 43.8 & \multirow{3}{*}{$0.516^{*}$} \\
\hline $1-3$ years & 12 & 36.4 & 13 & 40.6 & \\
\hline$>3$ years & 9 & 27.3 & 5 & 15.6 & \\
\hline \multicolumn{6}{|l|}{ Co-morbidities } \\
\hline No co-morbid disease & 8 & 24.2 & 8 & 25.0 & \multirow{3}{*}{$0.861 *$} \\
\hline 1 Co-morbid disease & 17 & 51.5 & 18 & 56.3 & \\
\hline$>1$ Co-morbid disease & 8 & 24.2 & 6 & 18.8 & \\
\hline
\end{tabular}

$*$ Chi-square test

\section{Effects of Peer Support Program on Self-Management of ESRD Patients}

Table 3 shows that after the peer support program, the mean score of self-management in the intervention group increased from $79.47 \pm 7.919$ to $90.75 \pm 7.089$, while in the control group, the mean increased from $81.88 \pm 8.291$ to $82.12 \pm 7.692$ with a p-value of $<0.001$. It can be concluded that there was a positive effect of peer support programs on increasing self-management in ESRD patients undergoing hemodialysis. 
Nurse Media Journal of Nursing, 10(2), 2020, 177

Table 3. Effects of peer support program on self-management before and after the intervention

\begin{tabular}{lcccc}
\hline \multicolumn{1}{c}{ Group } & $\begin{array}{c}\text { Before } \\
\text { Intervention }\end{array}$ & $\begin{array}{c}\text { After } \\
\text { Intervention }\end{array}$ & 95\% CI & \multirow{2}{*}{$P^{\mathrm{a}}$} \\
\cline { 2 - 3 } & Mean \pm SD & Mean \pm SD & & \\
\hline Intervention Group & $79.47 \pm 7.919$ & $90.75 \pm 7.089$ & $(-14.021)-(-$ & $<0.001$ \\
& & & $8.541)$ & \\
Control Group & $81.88 \pm 8.291$ & $82.12 \pm 7.692$ & $(-2.104)-(-1.619)$ & 0.793 \\
$P^{\mathrm{b}}$ & 0.235 & $<0.001$ & & \\
${ }^{\mathrm{a}}$ Paired-sample t-test, ${ }^{b}$ Independent-sample t-test. & & &
\end{tabular}

\section{DISCUSSION}

This study investigated the effects of peer support programs on improving selfmanagement in patients with ESRD undergoing HD. Results showed positive effects of peer support programs on increasing self-management of ESRD patients undergoing hemodialysis $(p<0.001)$. These findings are similar to a study previous that peer support with group discussions improved self-management ( $p<0.001)$ (Mahjubian et al., 2018). Another study also showed that one-to-one peer support (peer mentoring) affected dialysis self-management (Russell et al., 2017).

The success of HD cannot work if it only relies on a health team. The ability of patients' self-management to lifestyle changes such as consistent attendance at a dialysis unit for treatment, restriction of fluid intake, diet, and taking medications, influence the success of HD therapy (Li et al., 2014). Patients will be involved in self-management behaviors that are recommended if they have information and trust in health, self-regulation abilities and if they have social facilitation that positively influences and supports them to engage in preventive health behaviors. So that giving education to patients to improve their ability to control themselves also needs to involve social support in the form of information, emotional and instrumental support (Ryan, 2009; Ryan \& Sawin, 2009).

Knowledge, self-efficacy, and social support are factors that influence self-management in HD patients (Gela \& Mengistu, 2018; Li et al., 2014). Previous studies show that peer support in group discussion was an effective educational method to promote knowledge that improves the self-management of chronic HD patients (Mahjubian et al., 2018). Sufficient knowledge about the disease and problem-solving abilities are very important in the process of identifying problems, choosing the right solution, and evaluating its effects (Ryan, 2009). Knowledge is considered to foster the ability of self-confidence, self-efficacy, and patient compliance, especially in making decisions to carry out selfmanagement (Hibbard \& Gilburt, 2014).

Self-efficacy in HD patients is formed from a person's confidence in applying behavior and increasing efforts to solve problems faced to maintain these behaviors (Ryan, 2009). Self-efficacy is interpreted as a condition of personal self-confidence that can understand the way of one's thinking and motivation for active behavioral change when faced with obstacles or barriers (Williams \& Rhodes, 2016). Previous studies show that self-efficacy has been associated with self-management behaviors in chronic disease patients (Yao et al., 2019). To improve self-management behaviors, multiple strategies should be 
conducted to improve patients' self-efficacy. Social support is an important aspect to enhance self-efficacy, and previous studies have shown that a person's self-efficacy has a positive correlation with the social support they receive; that is, the more social support a person receives, the higher their self-efficacy is (Wang, $\mathrm{Qu}, \& \mathrm{Xu}, 2015$ ).

Social support has become an influencing factor in chronic disease patients' participation in health behavior (Pamungkas, Chinnawong, \& Kritpracha, 2015). Most HD patients do not work and spend a lot of time undergoing treatment, and social support becomes a very important requirement (Kusuma, Ropyanto, Widyaningsih, \& Sujianto, 2018). Patients who have better support tend to have a more positive state of mind in making better use of available resources to solve the problems they face (Li et al., 2014). Peer support happens when people who have similar experiences of something difficult come together to support each other (Side by Side Research Consortium, 2017). Peer support programs are carried out by sharing the experiences for improving HD self-management skills through informational support, emotional support, and mutual reciprocity (Husain, Kusuma, \& Johan, 2018; Taylor et al., 2016). Patients who are members of a group exchange experiences about various problems faced and also share about how to overcome these problems. This activity makes each patient feel they have the same problem, need each other, and can give support to each other (National Kidney Foundation, 2009). Patients may help each other in ways that health care providers may not be able to by sharing lived experiences and support (Russell et al., 2017). In this study, peer support program was conducted for six meetings, two times a week for 30-45 minutes each meeting to solve the problems together about fluid restriction management, nutrition and treatment management, and emotional management. Furthermore, the patients also had the opportunity to share their experiences with other patients, assessed problem solving, anticipated obstacles, and maintained new behaviors during the program. Such factors promoted problem-solving, anticipation of obstacles, and maintenance of new behaviors (Pamungkas et al., 2015). These methods made patients more confident in their abilities in order to deal with their conditions.

This study has limitations, researchers did not distinguish between self-management measurement between peer leaders and their members, because the selection of peer leaders was based on mutual agreement between group members. Some patients who have good self-management, are unable or unwilling to become peer leaders to lead the discussion. Thus, researchers as facilitators motivated patients who already had good selfmanagement to talk about self-management.

\section{CONCLUSION}

This study showed that peer support programs affected the increased self-management in patients with ESRD undergoing hemodialysis. Peer support programs should be introduced early to patients undergoing hemodialysis so that they can learn about selfmanagement from other patients. Patients may help each other in ways that health care providers may not be able to by sharing lived experiences and support. Further research can be conducted by involving a larger number of samples, providing communication training for peer leaders, and adding outcomes objectively to laboratory results. 


\section{ACKNOWLEDGMENT}

We sincerely thank the nurses and patients who participated in this study.

\section{CONFLICT OF INTEREST}

The authors declare no conflict of interest, financial or otherwise.

\section{REFERENCES}

Astuti, P. (2016). Determinan yang berhubungan dengan self management pasien gagal ginjal terminal yang menjalani hemodialisis di Kota Bekasi [Determinants related to self-management in end stage renal disease patients undergoing hemodialysis in Bekasi City] (Master's thesis). Universitas Indonesia.

Chen, Y., Chang, L., Liu, C., Ho, Y., Weng, S. C., \& Tsai, T. I. (2018). The roles of social support and health literacy in self-management among patients with chronic kidney. Journal of Nursing Scholarship, 50(3), 1-11. doi:10.1111/jnu.12377

Cozzolino, M., Mangano, M., Stucchi, A., Ciceri, P., Conte, F., \& Galassi, A. (2018). Cardiovascular disease in dialysis patients. Nephrology Dialysis Transplantation, 33, iii28-iii34. doi:10.1093/ndt/gfy174

Gela, D., \& Mengistu, D. (2018). Self-management and associated factors among patients with end-stage renal disease undergoing hemodialysis at health facilities in Addis Ababa, Ethiopia. International Journal of Nephrology and Renovascular Disease, 11, 329-336. doi:10.2147/IJNRD.S184671

Guney, I., Atalay, H., Solak, Y., Altintepe, L., Zeki Tonbul, H., \& Turk, S. (2012). Poor quality of life is associated with increased mortality in maintenance hemodialysis patients: a prospective cohort study. Saudi Journal of Kidney Diseases and Transplantation, 23(3), 493-499. doi:10.4103/1319-2442.95764

Haidari, A., Moeini, M., \& Khosravi, A. (2017). The impact of peer support program on adherence to the treatment regimen in patients with hypertension: A randomized clinical trial study. Iranian Journal of Nursing and Midwifery Research, 22(6), 427430. doi:10.4103/ijnmr.

Hibbard, J., \& Gilburt, H. (2014). Supporting people to manage their health: An introduction to patient activation. London: The King's Fund.

Husain, F., Johan, A., \& Kusuma, H. (2019). Peningkatan manajemen diri pasien penyakit ginjal tahap akhir yang menjalani hemodialisis: Literature review. [Improvement of sel-management in patients with end terminal of renal failure getting hemodialysis]. In Prosiding Seminar Nasional Kolaborasi Pendidikan dan Pelayanan Keperawatan dalam Era Revolusi Industri 4.0. Semarang: Faculty of Medicine, Universitas Diponegoro

Husain, F., Kusuma, H., \& Johan, A. (2018). Peer support program in hemodialysis patients: An analytical literature review. In Proceeding of 2nd International Conference of Translational Medicine and Health Sciences in conjunction with 4th Java International Nursing Conference 2018. Semarang: Faculty of Medicine, Diponegoro University.

Indonesian Renal Registry. (2018). 11th Report of Indonesian renal registry 2018. Retrieved from https://www.indonesianrenalregistry.org/data/IRR 2018.pdf 
Irajpour, A., Hashemi, M. S., Abazari, P., Shahidi, S., \& Fayazi, M. (2018). The effects of peer support on depression, anxiety, and stress among patients receiving hemodialysis. Iranian Red Crescent Medical Journal, 20(S1):e66321. doi:10.5812/ircmj.66321

Kusuma, H., Ropyanto, C. B., Widyaningsih, S., \& Sujianto, U. (2018). Relating factors of insomnia among hemodialysis patients. Nurse Media Journal of Nursing, 8(1), 4457. doi:10.14710/nmjn.v8i1.15741

Li, H., Jiang, Y., \& Lin, C. C. (2014). Factors associated with self-management by people undergoing hemodialysis: A descriptive study. International Journal of Nursing Studies, 51(2), 208-216. doi:10.1016/j.ijnurstu.2013.05.012

Lin, M. Y., Liu, M. F., Hsu, L. F., \& Tsai, P. S. (2017). Effects of self-management on chronic kidney disease: A meta-analysis. International Journal of Nursing Studies, 74, 128-137. doi:10.1016/j.ijnurstu.2017.06.008

Magalhaes, L. P., Dos Reis, L. M., Graciolli, F. G., Pereira, B. J., De Oliveira, R. B., De Souza, A. A. L., ... \& Jorgetti, V. (2017). Predictive factors of one-year mortality in a cohort of patients undergoing urgent-start hemodialysis. PLoS ONE, 12(1), 1-13. doi:10.1371/journal.pone.0167895

Mahjubian, A., Bahraminejad, N., \& Kamali, K. (2018). The effects of group discussion based education on the promotion of self-management behaviors in hemodialysis patients. Journal of Caring Sciences, 7(4), 225-232. doi:10.15171/jcs.2018.034

Malek-Khahi, A., Milani, M. J., \& Amiri, P. (2015). The effects of peer support groups on mental health of hemodialysis patients. Iran Journal of Nursing, 28(96), 40-49. doi:10.29252/ijn.28.96.40

Ministry of Health Republic of Indonesia (MoHRI). (2019). Laporan hasil riset kesehatan dasar (Riskesdas) Indonesia tahun 2018 [Report on the 2018 Indonesia's basic health research]. Retrieved from https://www.kemkes.go.id/resources/ download/info-terkini/hasil-riskesdas-2018.pdf

National Kidney Foundation. (2009). Benefits of peer support in people with chronic kidney disease. Retrieved from https://www.kidney.org/sites/default/files/docs/0210-4196_ebb_benefitsprofessionalflyer.pdf

Pamungkas, R. A., Chinnawong, T., \& Kritpracha, C. (2015). The effect of dietary and exercise self-management support program on dietary behavior exercise behavior and clinical outcomes in Muslim patients with poorly controlled type $2 \mathrm{DM}$ in a community setting in Indonesia. Nurse Media Journal of Nursing, 5(1), 1-14. doi:10.14710/nmjn.v5i1.10186

Rijken, M., Jones, M., Dixon, M., \& Anna, H. (2008). Supporting self-management. In E. Nolte \& M. McKee (Eds.). Caring for people with chronic condition: A health system perspective. England: McGraw-Hill Education.

Robinson, B. M., Zhang, J., Morgenstern, H., Bradbury, B. D., Ng, L. J., Mccullough, K. P., .. \& Pisoni, R. L. (2014). Worldwide mortality risk is high soon after initiation of hemodialysis. Kidney International, 85, 158-165. doi:10.1038/ki.2013.252

Russell, J. S. C., Southerland, S., Huff, E. D., Thomson, M., Meyer, K. B., \& Lynch, J. R. (2017). A peer-to-peer mentoring program for in-center hemodialysis: A patientcentered quality improvement program. Nephrology Nursing Journal, 44(6), 481496. 
Ryan, P. (2009). Integrated theory of health behavior change background and intervention. Clinical Nurse Specialist, 23(3), 161-170. doi:10.1097/NUR.0b013e3181a42373

Ryan, P., \& Sawin, K. (2009). The individual and family self-management theory: background and perspectives on context, process, and outcomes. Nursing Outlook, 57(4), 217-225. doi:10.1016/j.outlook.2008.10.004.

Saran, R., Robinson, B., Abbott, K. C., Bragg-Gresham, J., Chen, X., Gipson, D., ..., \& Shahinian, V. (2019). US renal data system 2019 annual data report: Epidemiology of kidney disease in the United States. American Journal of Kidney Disease, 75(1 Suppl 1), A6-A7. doi: 10.1053/j.ajkd.2019.09.003

Side by Side Research Consortium. (2017). Developing peer support in the community: A toolkit. London: Mind.

Smeltzer, S. C., Bare, B. G., Hinkle, J. L., \& Cheever, K. H. (2010). Brunner \& Suddarth's textbook of medical-surgical nursing (12th ed.). Philadelphia: Lippincott Williams \& Wilkins.

Taylor, F., Gutteridge, R., \& Willis, C. (2016). Peer support for CKD patients and carers: Overcoming barriers and facilitating access. Health Expectations, 19(3), 617-630. doi:10.1111/hex.12348

Wang, C.-M., Qu, H.-Y., \& Xu, H.-M. (2015). Relationship between social support and self-efficacy in women psychiatrists. Chinese Nursing Research, 2(4), 103-106. doi:10.1016/j.cnre.2015.10.002

Wang, H., Naghavi, M., Allen, C., Barber, R. M., Carter, A., Casey, D. C., ..., \& Zuhlke, L. J. (2016). Global, regional, and national life expectancy, all-cause mortality, and cause-specific mortality for 249 causes of death, 1980-2015: A systematic analysis for the Global Burden of Disease Study 2015. The Lancet, 388(10053), 1459-1544. doi:10.1016/S0140-6736(16)31012-1

Williams, D. M., \& Rhodes, R. E. (2016). The confounded self-efficacy construct: Conceptual analysis and recommendations for future research. Health Psychology Review, 10(2), 113-128. doi:10.1080/17437199.2014.941998

Yao, J., Wang, H., Yin, X., Yin, J., Guo, X., \& Sun, Q. (2019). The association between self-efficacy and self-management behaviors among Chinese patients with type 2 diabetes. PLOS ONE, 14(11), e0224869.

Yin, J., Wong, R., Au, S., Chung, H., Lau, M., Lin, L., .., \& Chan, J. C. N. (2015). Effects of providing peer support on diabetes management in people with type 2 diabetes. Annals of Family Medicine, 13 Suppl 1(Suppl 1), S42-S49. doi:10.1370/afm.1853 